\title{
THE EFFECT OF NATURAL AND HUMAN-INDUCED HABITAT CONDITIONS ON NUMBER OF ROE DEER: CASE STUDY OF VOJVODINA, SERBIA
}

Vladimir N. Marković, Djordjije A. Vasiljević, Tamara Jovanović, Tin Lukić, Miroslav D. Vujičić, Milutin Kovačević, Zoran A. Ristić, Slobodan B. Marković, Branko Ristanović, Dušan Sakulski

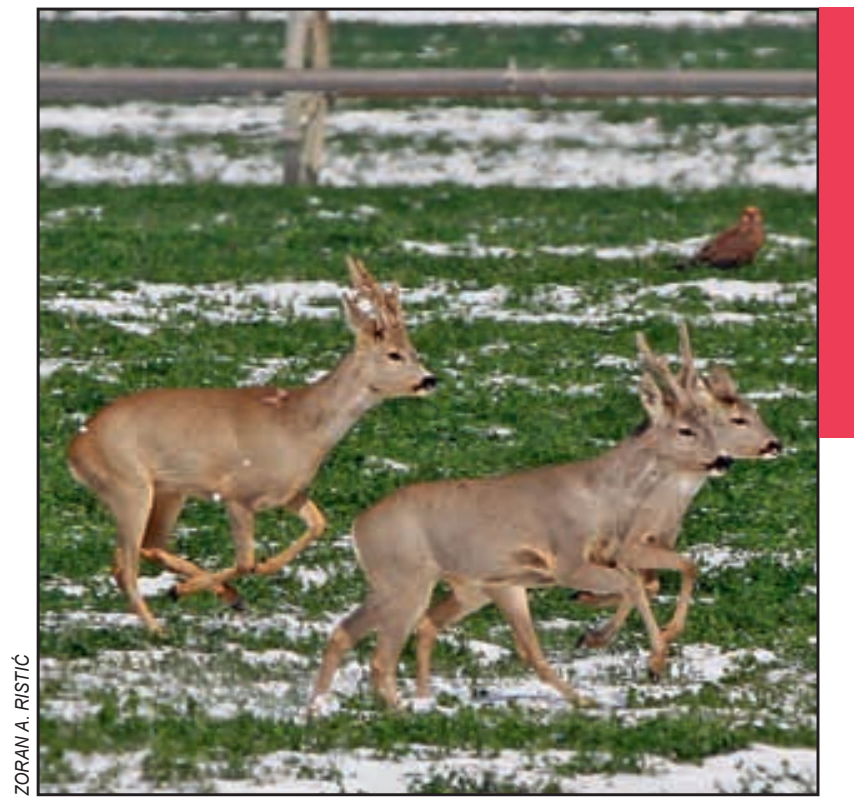

Roe deer in natural habitat. 


\title{
The effect of natural and human-induced habitat conditions on number of roe deer: case study of Vojvodina, Serbia
}

\author{
DOI: http://dx.doi.org/AGS.903 \\ UDC: 913:591.522(497.113) \\ 591.522:599.735.341(497.113) \\ COBISS: 1.01
}

\begin{abstract}
Roe deer (Capreolus capreolus L.) have greatly expanded in both distribution and abundance during the last few decades, and are the most abundant cervids in Europe today. The aim of this paper is to determine the factors that have the most considerable impact on roe deer numbers in the Vojvodina region (North Serbia). Environmental (area in ha, total area of forest and total area of meadows and pastures in hunting ground) and anthropogenic (number of registered hunters, number of hunting sections, number of gamekeepers and roads in $\mathrm{km}$ on 1,000 ha) factors had been shown to influence the number of roe deer in Vojvodina region. A multiple regression analysis was carried out as the main statistical approach. The mapping of certain parameters was done using ArcGIS 9.2 software in order to establish the relation between the roe deer population and the different environmental and anthropogenic conditions. The results signify that the roe deer number dependency in the Vojvodina region is a very complex and multi-factorial phenomenon, strongly influenced by human induced modifications.
\end{abstract}

KEY WORDS: geography, environmental protection, roe deer number, habitat, hunting, regression model, GIS, Vojvodina, Serbia

The article was submitted for publication on August $8^{\text {th }}, 2014$.

ADRESSES:

Vladimir N. Marković, Ph.D.

Department of Geography, Tourism and Hotel Management Faculty of Sciences, University of Novi Sad

Trg Dositeja Obradovića 3, RS - 21000 Novi Sad, Serbia

E-mail: vladimir.markovic@dgt.uns.ac.rs

Djordjije A. Vasiljević, Ph.D.

Department of Geography, Tourism and Hotel Management Faculty of Sciences, University of Novi Sad

Trg Dositeja Obradovića 3, RS - 21000 Novi Sad, Serbia

E-mail: vasiljevic80@gmail.com

Tamara Jovanović, Ph.D.

Department of Geography, Tourism and Hotel Management Faculty of Sciences, University of Novi Sad

Trg Dositeja Obradovića 3, RS - 21000 Novi Sad, Serbia

E-mail: tamara.jovanovic@dgt.uns.ac.rs

Tin Lukić, Ph.D.

Department of Geography, Tourism and Hotel Management Faculty of Sciences, University of Novi Sad

Trg Dositeja Obradovića 3, RS - 21000 Novi Sad, Serbia

E-mail: tin.lukic@dgt.uns.ac.rs 


\section{Miroslav D. Vujičić, Ph.D.}

Department of Geography, Tourism and Hotel Management Faculty of Sciences, University of Novi Sad

Trg Dositeja Obradovića 3, RS - 21000 Novi Sad, Serbia

E-mail: miroslav.vujicic@dgt.uns.ac.rs

\section{Milutin Kovačević M.Sc.}

Department of Geography, Tourism and Hotel Management Faculty of Sciences, University of Novi Sad

Trg Dositeja Obradovića 3, RS - 21000 Novi Sad, Serbia

E-mail: milutin.kovacevic@dgt.uns.ac.rs

\section{Zoran A. Ristić, Ph.D.}

Department of Geography, Tourism and Hotel Management Faculty of Sciences, University of Novi Sad

Trg Dositeja Obradovića 3, RS - 21000 Novi Sad, Serbia

E-mail: balzakova@yahoo.com

\section{Slobodan B. Marković, Ph.D.}

Department of Geography, Tourism and Hotel Management Faculty of Sciences, University of Novi Sad

Trg Dositeja Obradovića 3, RS - 21000 Novi Sad, Serbia

E-mail: slobodan.markovic@dgt.uns.ac.rs

\section{Branko Ristanović, Ph.D.}

Department of Geography, Tourism and Hotel Management Faculty of Sciences, University of Novi Sad

Trg Dositeja Obradovića 3, RS - 21000 Novi Sad, Serbia

E-mail: branko.ristanovic@dgt.uns.ac.rs

\section{Dušan Sakulski, Ph.D.}

Department of Environmental Engineering and Occupational Safety and Health Faculty of Technical Sciences, University of Novi Sad

Trg Dositeja Obradovića 6, RS - 21000 Novi Sad, Serbia and Disaster Management Training and Education Centre (DiMTEC) University of the Free State 205 Nelson Mandela Drive, Park West, ZA - 9300 Bloemfontein, South Africa E-mail: dsakulski2@me.com 


\section{Introduction}

During the last few decades, roe deer (Capreolus capreolus L.) have greatly expanded in both distribution and abundance, and today they are the most abundant cervids in Europe (Andersen, Duncan and Linnel 1998; Mysterud and Østbye 2004; Apollonio, Andersen and Putman 2010; Torres et al. 2011) as well as the most extensively studied ungulates (Andersen, Duncan and Linnell 1998).

Although generally considered as a typical forest specie, recent studies proved roe deer's ability to inhabit physically diverse areas and could be found in almost all European landscapes (Hewison et al. 2001; Jepsen and Topping 2004, Torres et al. 2011).

The Vojvodina region (North Serbia) is characterised by vast areas of steppe, wetlands, ponds and forests, which are favourable habi-tats for numerous and diverse game species (Ristić, Marković and Dević 2009). The number of roe deer within the investigated area varies among hunting associations. According to the data from 2000, the average number of roe deer in Vojvodina is 17.6 heads on 1,000 ha. The long-term hunting development plan 2001-2010 (Hunting association ... 2000), predicted a 49.03\% rise in the number of roe deer, which should bring the number of roe deer to 26.2 heads on 1,000 ha in 2010 . The data from 2010 are not currently available, but according to the last available data, from 2009 , the number has raised to 25.4 heads on 1,000 ha. The aim of this paper is to determine the factors with the most considerable impact on the number of roe deer in the investigated area. Although this species' habitat is widely influenced by a range of biogeographical factors operating at different scales (Torres et al. 2011), recent researches have determined that available food (Virgós and Telléria 1998) and land cover (Mysterud and Østbye 1999; Borkowski 2004; Borkowski and Ukalska 2008; Melis et al. 2009) are two essential factors. These factors play a critical part in shaping this species' habitat selection, which in turn affects the number of roe deer. However, Torres et al. (2011) consider several other factors that could also affect its population, including human interference and disturbance (Aragón, Braza and San José 1995; Hewison et al. 2001), topography (Mysterud and Østbye 1999), and climatic factors (Brewka and Kossak 1994). This research combines quantitative data on certain factors suggested to have the biggest impact on roe deer habitat suitability in order to determine the most influential ones. Environmental (area in ha, total area of forest and total area of meadows and pastures in hunting ground) and anthropogenic (number of registered hunters, number of hunting sections, number of gamekeepers and roads in $\mathrm{km}$ on 1,000 ha) factors influence the number of roe deer in Vojvodina region.

\section{Materials and methods}

\subsection{Method}

\subsubsection{Sample}

The study area includes 57 hunting grounds (Figure 1) that correspond with the municipality areas - except for the Kikinda, Vršac, Srbobran and Ada municipalities with more than one hunting ground on their area. The hunting grounds are unfenced and managed by the Provincial Secretariat for Agriculture, Forestry and Water Management. The game on these hunting grounds is self-reliant and only influenced by human induced environmental improvements. The following hunting grounds were excluded from the study because they are fenced off and supports different habitat conditions: The hunting grounds of National Park »Fruška gora «; hunting grounds in possession of military of Serbia; Public Company »Vojvodina šume «; and hunting grounds owned by agricultural and fish ponds companies.

\subsubsection{Hypotheses}

The following hypotheses were postulated:

1) The number of roe deer is influenced by natural factors: Total area of hunting ground in hectares; total area of forest on hunting ground in hectares; and total area of meadows and pastures on hunting ground in hectares.

Figure 1: The map of roe deer dissemination in the Vojvodina region (Antonić and Beuković 2007; modified). 
Acta geographica Slovenica, 57-2, 2017

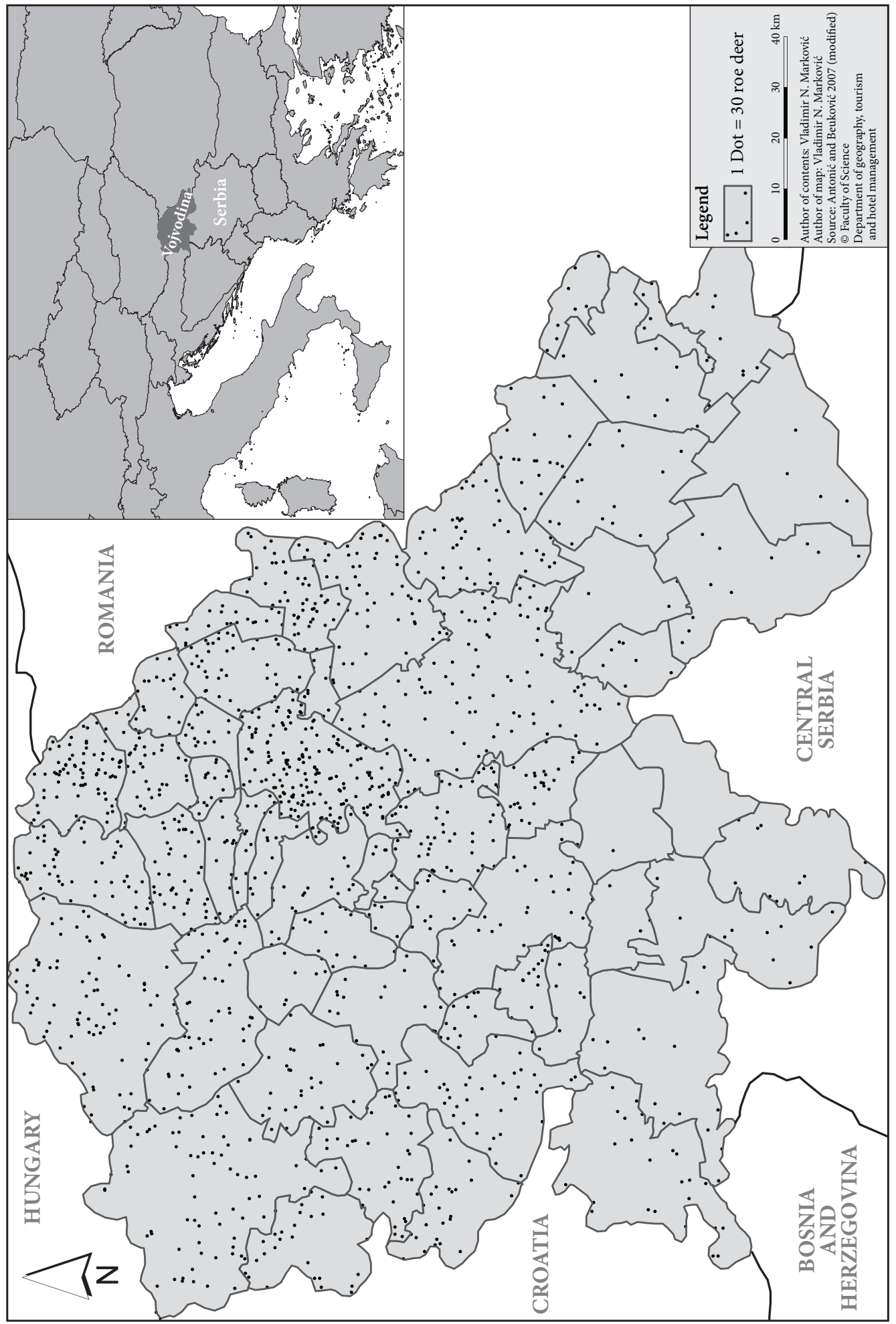


All above listed natural factors positively influence the number of roe deer. Numerous researches (e.g. Mysterud, Lian and Hermann 1999); Bokalo 2001; Partl 2001; Partl 2002; Borkowski 2004; Hemani, Watkinson and Dolman 2005; Toïgo et al. 2008; Popović et al. 2009; Reimosera et al. 2009) support this claim. 2) The number of roe deer is influenced by human induced factors: Number of registered hunters; number of hunting sections; number of gamekeepers; and roads in $\mathrm{km}$ on 1,000 ha of hunting ground.

The number of registered hunters, number of hunting sections, number of residents in the municipality and roads in $\mathrm{km}$ on 1,000 ha of hunting ground have a negative influence on the number of roe deer. The number of gamekeepers correlates positively with the number of roe deer. Many researchers have examined these factors and their impact on the number of game (e.g. Stedman et al. 2004; Blumstein et al. 2005; Borkowski and Ukalska 2008; Jayakody et al. 2008; Stankowich 2008; Torres et al. 2011).

\subsubsection{Procedure}

This study used data on the condition and number of game (including roe deer) obtained from the laboratory of Hunting Association of Vojvodina. Beside the number of game, the data also include: vegetation structure variability; infrastructure changes; various demographic data (hunters' number, age, gender); and other variables that could influence the game habitat and number. In order to establish the relation between roe deer population and different environmental and anthropogenic conditions, mapping of certain parameters was done using ArcGIS 9.2 software.

\subsubsection{Statistical approach}

A multiple regression analysis was carried out using SPSS 17 software for statistical computing. Before the analysis, three hunting grounds were excluded because their number of roe deer was either too small or two large in comparison with the other hunting grounds ( \pm 2 standard deviations). A log-transformation of the dependent variable number of roe deer was performed in order to normalise its distribution. Predictor variables were: Total area of hunting ground in hectares; number of registered hunters; number of hunting sections; number of gamekeepers; total area of forest on hunting ground in hectares; total area of meadows and pastures on hunting ground in hectares; and roads in $\mathrm{km}$ on 1,000 ha of hunting ground. The criterion variable was the log-transformed number of roe deer.

\section{Results}

The results of the above mentioned multiple regression analysis are shown in table 1 . The analysis of the results shows that the overall regression model is significant $(\mathrm{r}=0.648 ; \mathrm{r} 2=0.420 ; \mathrm{F}(6.47)=4.071 ; \mathrm{p}<0.01)$. Only the area in ha, number of registered hunters and number of hunting sections show a statistically significant influence. The area of the hunting ground and number of registered hunters has a significant positive impact on the number of roe deer. However, the number of hunting sections has a significant negative impact on the number of roe deer. No effect of a multicollinearity problem is detected in the model as all the VIF scores are smaller than 10 and Tolerance values are larger than 0.1 (Figure 2).

\section{Discussion}

The results show that a larger surface area has a larger number of roe deer (Table 1). The smaller the area, the more negatively it affects game habitat in terms of seasonality, lack of shelters, and uniformed food supplies - all of which contribute to the decrease in the number of roe deer. According to Law on Game and Hunting (Zakon o divljači i lovstvu 2010), a minimum of $20 \%$ of each hunting ground must be protected as reserves, where all human activities related to hunting and animal disturbance are prohibited. This ensures safer reproducing conditions and protection of the roe deer offspring. Larger hunting ground (HG) will evidently have larger reserves. Commonly, each of the hunting grounds in the Vojvodina region is within only one municipality and is managed by its hunting association (Figure 3 ).

As there is no universal management model, each hunting ground operates independently, resulting in temporal and spatial discordance. Hunters' ethical behaviour is under question because there is no integral and internal control - it varies between sections and could lead to increased poaching and illegal hunting. This has all been proven in the regression model (Table 1). 
Acta geographica Slovenica, 57-2, 2017

Table 1: The regression model of certain factors influencing the number of roe deer of the investigated area.

\begin{tabular}{lccccc}
\hline & $\beta$ (weight) & t-test & $p$ (significance) & Tolerance & VIF \\
\hline $\begin{array}{l}\text { Total hunting ground area in ha } \\
\begin{array}{l}\text { Number of registered hunters } \\
\text { without hunter-tourists }\end{array}\end{array}$ & 0.488 & 2.498 & 0.02 & 0.337 & 2.96 \\
\hline $\begin{array}{l}\text { Number of semi-independent } \\
\text { hunting clubs within the hunting } \\
\text { associations }\end{array}$ & -0.524 & -2.46 & 0.02 & 0.337 & 2.97 \\
\hline $\begin{array}{l}\text { Number of gamekeepers } \\
\text { without volunteers }\end{array}$ & 0.05 & 0.299 & 0.77 & 0.284 & 3.52 \\
$\begin{array}{l}\text { roads in km on 1,000 ha } \\
\text { of hunting ground }\end{array}$ & -0.018 & -0.13 & 0.9 & 0.466 & 2.15 \\
\hline $\begin{array}{l}\text { total area of meadows and pastures } \\
\text { on hunting ground in hectares }\end{array}$ & 0.135 & 1.117 & 0.27 & 0.665 & 1.5 \\
\hline $\begin{array}{l}\text { total area of forest on the hunting } \\
\text { ground in hectares }\end{array}$ & -0.04 & -0.3 & 0.77 & 0.712 & 1.13 \\
\hline
\end{tabular}

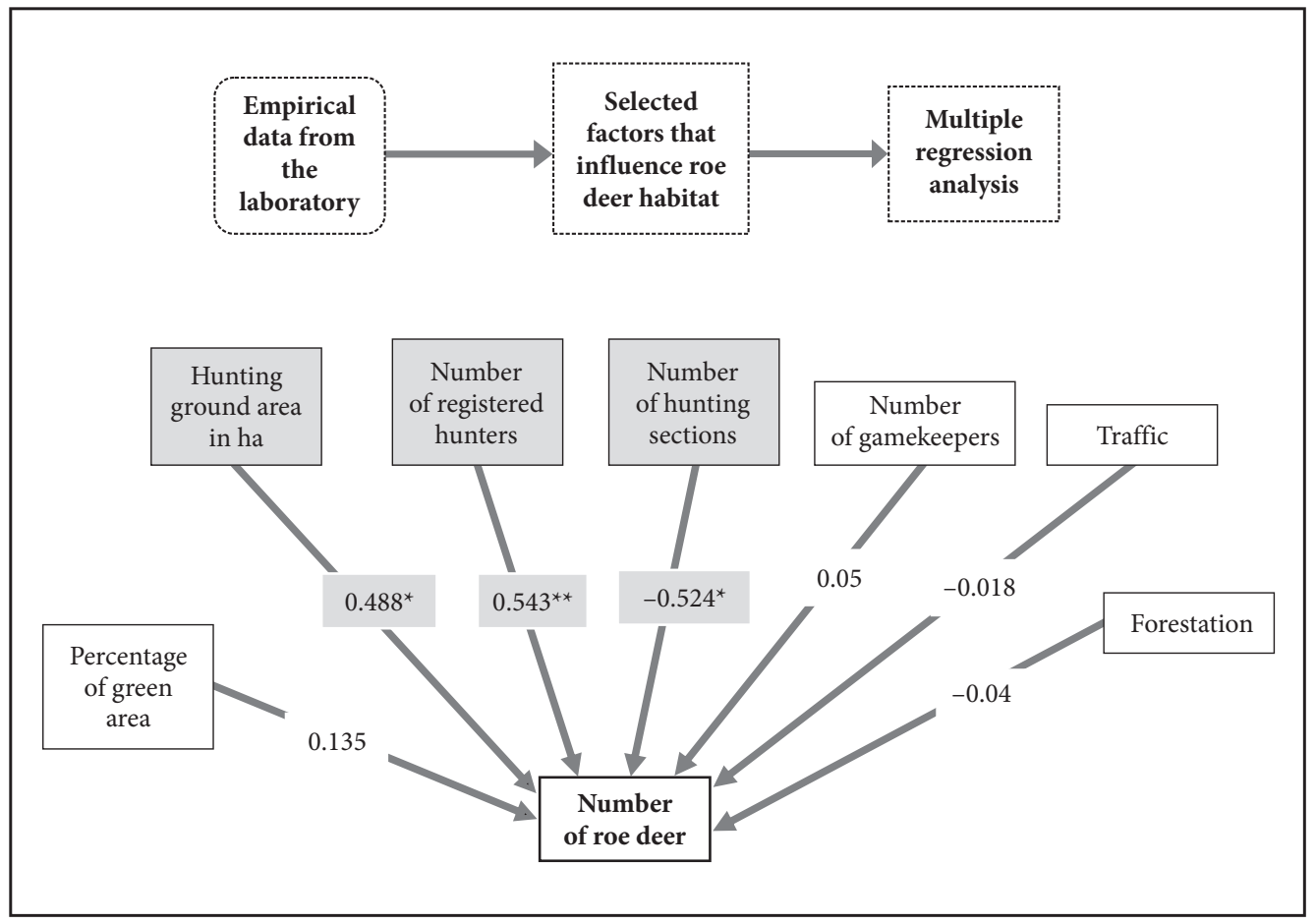

Figure 2: Graphic presentation of regression model.

Figure 3: Quantification of hunting factors by hunting grounds (Antonić and Beuković 2007; modified). > p. 64

Figure 4: Traffic network density (km/1,000 ha) by hunting grounds in the Vojvodina region (Source: Statistical Office of the Republic of Serbia 2008; modified) $>$ p. 65

Figure 5: Forestation and area of meadows and pastures of hunting grounds in the Vojvodina region (Statistical Office of the Republic of Serbia 2008; modified). $>$ p. 66 
The effect of natural and human-induced habitat conditions on number of roe deer: case study of Vojvodina, Serbia

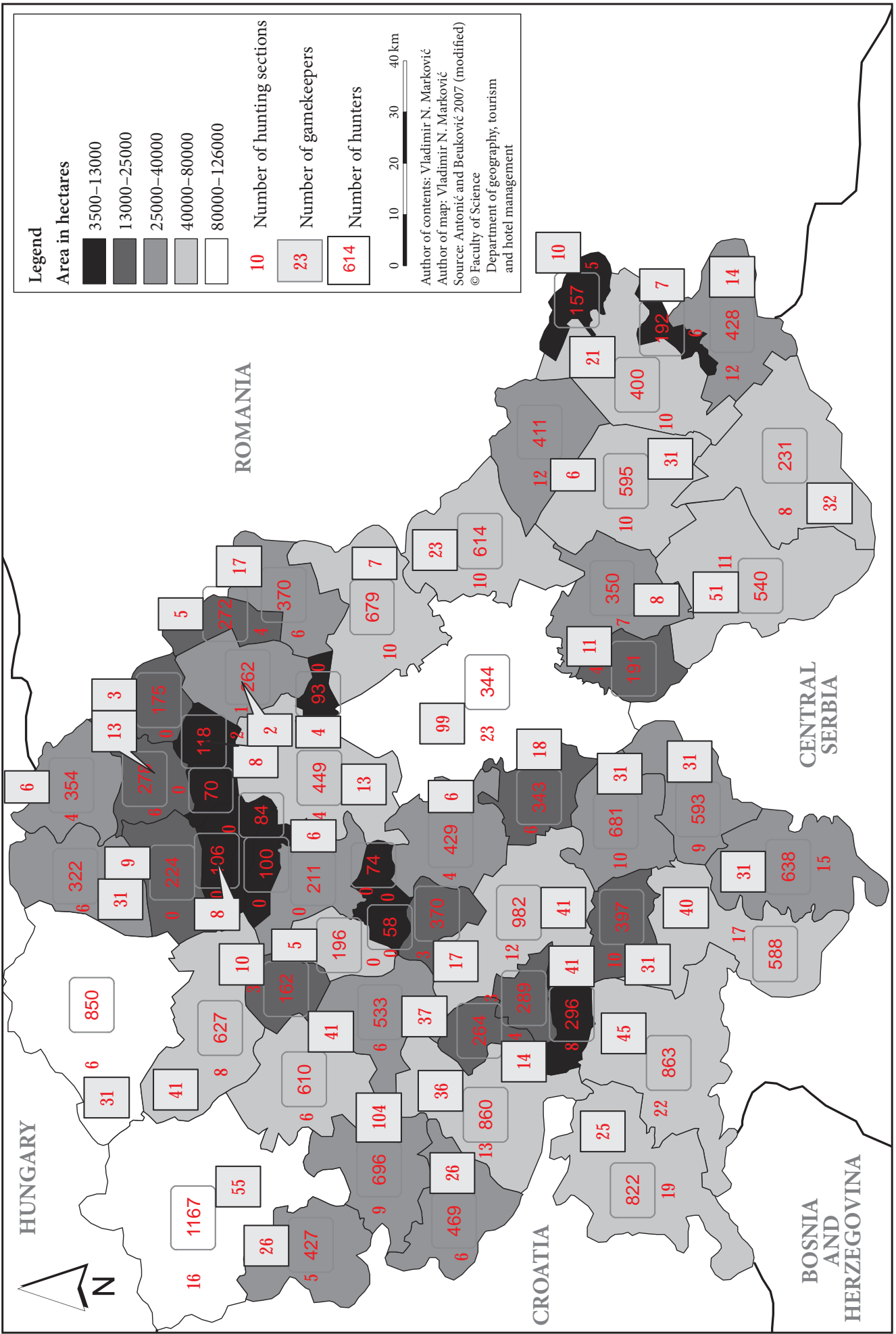


Acta geographica Slovenica, 57-2, 2017
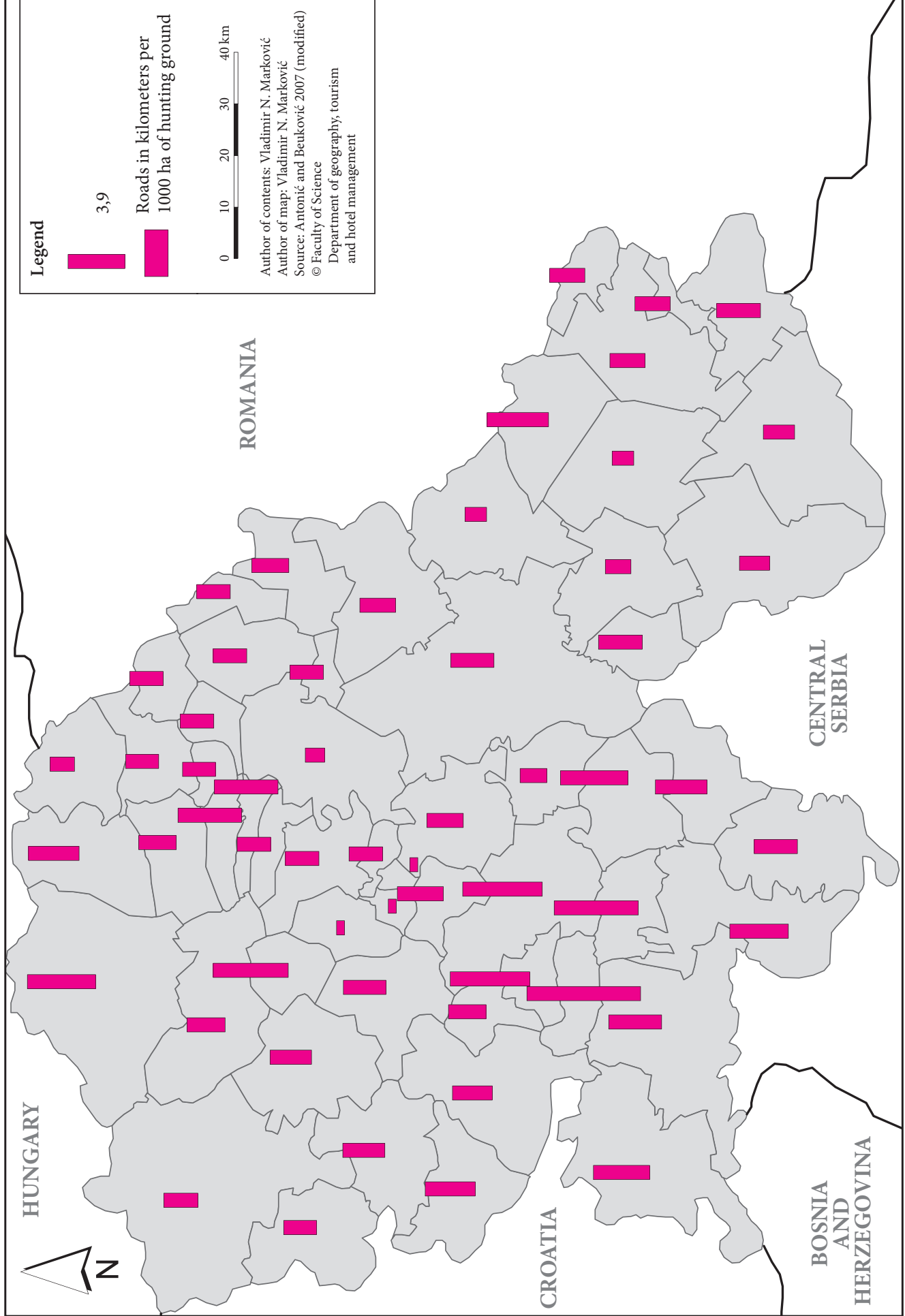
The effect of natural and human-induced habitat conditions on number of roe deer: case study of Vojvodina, Serbia
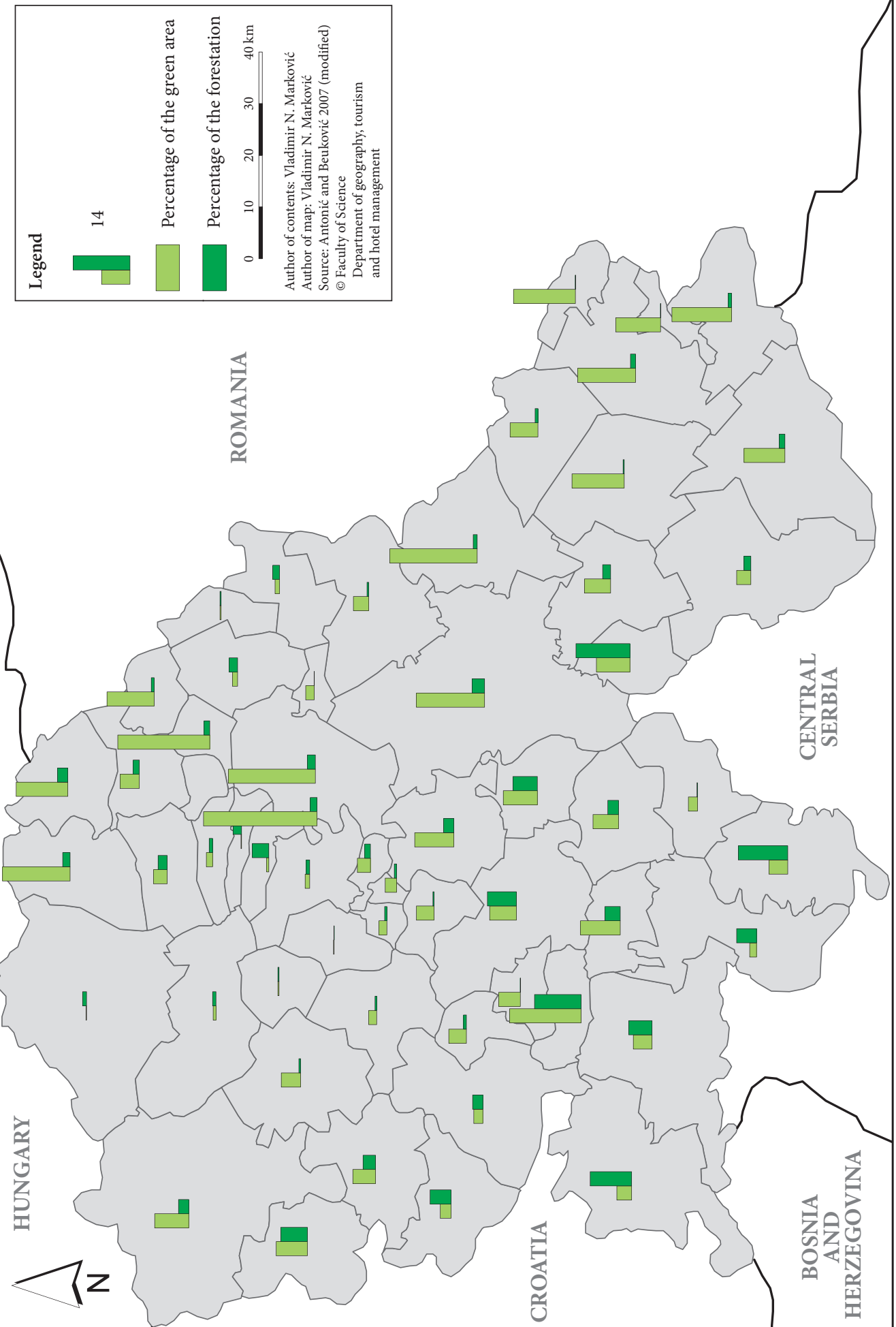
Roe deer generally avoid areas that are intensively used by humans (Mysterud, Lian and Hermann 1999). However, this study found that the number of registered hunters is directly proportional to the number of roe deer game. This might be due to increased income generated by the hunter's membership fees that is used for game food and medicaments, breeding and feeding facilities. Also, larger hunter numbers result in better and more efficient care of game, especially concerning annual procedures such as game counting, feeder and salt lick instalment, maintenance and repair of breeding and feeding facilities, or even game rescue during natural hazards (floods, fires, snow, etc.). The role of hunters in these situations is crucial, as hunting ground quality depends on their assistance. According to Marković et al. (2011), most of the registered hunters in Vojvodina (46.7\%) have stated that linking with nature is the primary motive for engaging in hunting.

In contrast to number of hunters, number of gamekeepers does not affect the number of roe deer game. We believe that this is mostly the case because in the investigated area most of the gamekeepers work voluntarily and thus their commitment to duty could be questionable. Consequently, the latest Law on Game and Hunting (Zakon o divljači i lovstvu 2010) enacted by Ministry of Agriculture, Trade, Forestry and Water Management of the Republic of Serbia, revoked the title gamekeeper-volunteer. According to Marković (2010), the level of gamekeeper-volunteers' adequate expertise and knowledge in Vojvodina has shown considerable variability.

The length of roads in the investigated area has no effect on roe deer number, although it was expected to have a negative influence (e.g. Mysterud 1999; Hewison et al. 2001; Torres et al. 2011). This could be justified by the fact that average traffic network density in the Vojvodina region is only $2.93 \mathrm{~km} / 1,000$ ha (of hunting ground) (Figure 4).

The total area of meadows and pastures on hunting ground in hectares, and total area of forest on hunting ground in hectares are insignificant parameters (Table 1), unlike in the findings of previous researches (e.g. Reimoser and Zandl 1993; Partl 2001 and 2002; Bokalo 2001; Borkowski and Ukalska 2008; Reimosera et al. 2009). Vojvodina is one of the European regions with poorest forest areas (only $5.5 \%$ of the territory is covered by forest) (Figure 5). Furthermore, most of the forests are located within nature reserves (outside of hunting grounds), which leaves investigated area with average forestation of only $1.7 \%$ (Marković 2010). On the other hand, comparing three forest management models - no harvest, single tree selection and clear-cut - the clear cut gives the best habitat quality for roe deer, which indicate that forestation is not necessarily an essential parameter for roe deer habitat (Vospernik and Reimoser 2008). We also believe that the area of meadows and pastures is an insignificant predictor for the number of roe deer, mostly due to vast areas under agricultural crops with addition of feeding facilities that provide sufficient food supply for roe deer population.

\section{Conclusion}

This study's results and discussions signify that the roe deer number dependency in the Vojvodina region is a very complex and multi-factorial phenomenon, but strongly influenced by human-induced modifications of habitat. Unfortunately, as a typical Pannonian landscape with a high level of cultivation (Antonić and Beuković 2007), the Vojvodina region offers limited conditions for wildlife habitat (Suchant, Baritz and Braunisch 2003).

These agricultural regions, or "agroecosystems " (Knoche and Lupi 2004) present the most important and pervasive type of managed ecosystem (Antle and Capalbo 2002). It is located on the most productive land, covering $30 \%$ of the earth's land area, and $80 \%$ in the Vojvodina region (Antonić and Beuković 2007). Consequently, the establishment of agriculture and hunting grounds could influence natural habitats (Knoche and Lupi 2004), with certain conflicts arising between wildlife management and protection on the one hand, and the utilisation of the land for tourism and economic exploitation on the other (Suchant, Baritz and Braunisch 2003).

Inevitably, there is a formal opinion that (particularly in Vojvodina region) roe deer and ungulates in general, with habitats outside protected areas, could not survive in those numbers if there were no hunting grounds. A great danger to the roe deer population could emerge with uncontrolled hunting, cold and dry periods with poor land cover, food and water supplies, increased cultivated areas, etc. All of these factors are generally prevented by the efficient and devoted work of hunting associations with the application of adequate biogeographical surveys and strategies. 
ACKNOWLEDGEMENT: This work was supported by the Ministry of Science and Technological Development, Republic of Serbia (grant 176020) and the Provincial Secretariat for Science and Technological Development, Vojvodina Province, Serbia (grant 114-451-2644/2012-01).

\section{References}

Andersen, R., Duncan, P., Linnell, J. D. C. 1998: The European roe deer: the biology of success. Oslo.

Antle, J., Capalbo, S. 2002: Agriculture as a managed ecosystem: implications for econometric analysis of production risk. A comprehensive assessment of the role of risk in U.S. Agriculture. Boston.

Antonić, D., Beuković, M. 2007: Hunting organization of Vojvodina. Novi Sad.

Apollonio, M., Andersen, R., Putman, R. 2010: European ungulates and their management in the 21st century. New York.

Aragón, S., Braza, F., San José, C. 1995: Socioeconomic, physiognomic, and climatic factors determining the distribution pattern of roe deer Capreolus capreolus in Spain. Acta theriologica 40-1. DOI: http://dx.doi.org/ 10.4098/AT.arch.95-4; oai:rcin.org.pl:12369

Blumstein, D. T., Fernandez-Juricic, E., Zollner, P.A., Garity, S.C. 2005: Inter-specific variation in avian responses to human disturbance. Journal of applied ecology 42-5. DOI: http://dx.doi.org/10.1111/ j.1365-2664.2005.01071.x

Bokalo, M. 2001: The role of forest growth in habitat quality dynamics. Wien.

Borkowski, J. 2004: Distribution and habitat use by red and roe deer following a large forest fire in Southwestern Poland. Forest ecology and management 201, 2-3. DOI: http://dx.doi.org/10.1016/j.foreco.2004.07.011

Borkowski, J., Ukalska, J. 2008: Winter habitat use by red and roe deer in pine-dominated forest. Forest ecology and management 255, 3-4. DOI: http://dx.doi.org/10.1016/j.foreco.2007.09.013

Brewka, A., Kossak, S. 1994: The influence of atmospheric conditions on the mobility of roe deer (Capreolus capreolus L.) in winter. Ekologia Polska 40-2.

Hemani, M. R., Watkinson, A. R., Dolman, P. M. 2005: Population densities and habitat associations of introduced muntjac Muntiacus reevesi and native roe deer Capreolus capreolus in a lowland pine forest. Forest ecology and management 215, 1-3. DOI: http://dx.doi.org/10.1016/j.foreco.2005.05.013

Hewison, A. J., Vincent, J. P., Joachim, J., Angibault, J. M., Cargnelutti, B., Cibien, C. 2001: The effects of woodland fragmentation and human activity on roe deer distribution in agricultural landscapes. Canadian journal of zoology 79-4. DOI: http://dx.doi.org/10.1139/z01-032

Hunting association of Vojvodina, 2000: Long-term hunting development plan in Vojvodina 2001-2010. Novi Sad.

Jayakody, S., Sibbald, A. M., Gordon, I. J., Lambin, X. 2008: Red deer Cervus elaphus vigilance behaviour differs with habitat type and human disturbance. Wildlife biology 14-1. http://dx.doi.org/10.2981/ 0909-6396(2008)14[81:RDCEVB]2.0.CO;2

Jepsen, J. U., Topping, C. J. 2004: Modelling roe deer (Capreolus capreolus) in a gradient of forest fragmentation: behavioural plasticity and choice of cover. Canadian journal of zoology 82-9. DOI: http://dx.doi.org/ 10.1139/z04-131

Knoche, S., Lupi, F. 2004: Valuing deer hunting ecosystem services from farm landscapes. Ecological economics 64-2. DOI: http://dx.doi.org/10.1016/j.ecolecon.2007.07.023

Marković, V. 2010: Primena geografskih informacionih tehnologija u lovnom turizmu Vojvodine. Doktorska disertacija, Prirodno-matematički fakultet Univerziteta u Novom Sadu. Novi Sad.

Marković, V., Davidović, N., Djurdjev, B., Dragin, A. 2011: Influence of age and educational structure on the behavior of hunters in Vojvodina Province (Serbia). Turizam 15-4.

Melis, C., Jedrzejewska, B., Apollonio, M., Barton, K., Jedrzejewski, W., Linnell, J., Kojola, I., Kusak, J., Adamic, M., Ciuti, S., Delehan, I., Dykyy, I., Krapinec, K., Mattioli, K., Sagaydak, A., Samchuk, N., Schmidt, K., Shkvyrya, M., Sidorovich, V., Zawadzka, B., Zhyla, S. 2009: Predation has a greater impact in less productive environments: variation in roe deer, Capreolus capreolus, population density across Europe. Global ecology and biogeography 18-6. DOI: http://dx.doi.org/10.1111/j.1466-8238.2009.00480.x

Mysterud, A. 1999: Seasonal migration pattern and home range of roe deer (Capreolus capreolus) in an altitudinal gradient in southern Norway. Journal of zoology 247-4. DOI: http://dx.doi.org/10.1111/ j.1469-7998.1999.tb01011.x 
Mysterud, A., Lian, L.B., Hermann, D.Ø. 1999: Scale-dependent trade-offs in foraging by European roe deer (Capreolus capreolus) during winter. Canadian journal of zoology 77-9. DOI: http://dx.doi.org/10.1139/ z99-118

Mysterud, A., Østbye E. 1999: Cover as a habitat element for temperate ungulates: effects on habitat selection and demography. Wildlife society bulletin 27-2.

Mysterud, A., Østbye, E. 2004: Roe deer (Capreolus capreolus) browsing pressure affects yew (Taxus baccata) recruitment within nature reserves in Norway. Conservation biology 120-4. DOI: http://dx.doi.org/ 10.1016/j.biocon.2004.03.027

Partl, E. 2001: Die Wechselwirkungn zwischen Wald als Habitat und Rehwild als Standortfaktor bei der Waldsanierung. Modellbildung und Wissensrepräsentation im Rahmen der Entwicklung des Expertensystems »Wildökologie - Waldverjüngung«. PhD thesis, Gesellschaft für Waldökosystemforschung und experimentelle Baumforschung in Universität für Bodenkultur. Wien.

Partl, E. 2002: Expertensystem »Wildökologie - Waldverjüngung«- Modellierung der Wechselwirkungen zwischen Waldhabitat und Rehwild. Berlin.

Popović, Z., Đorđević, N., Grubić, G., Stojanović, B. 2009: Estimation of the quality of the nutrition of roe deer based on chemical composition of the rumen content. Acta veterinaria 59-5. https://doi.org/10.2298/ AVB0906653P

Reimoser, F., Zandl, J. 1993: Methodisches Grundkonzept für ein Expertensystem »Wildökologie Waldverjüngung«, Anwendungsbeispiel FIW II - Fallstudie 1 (Schöneben/Oberösterreich). Wien.

Reimosera, S., Partl, E., Reimoser, F., Vospernik, S. 2009: Roe-deer habitat suitability and predisposition of forest to browsing damage in its dependence on forest growth - model sensitivity in an Alpine forest region. Ecological modelling 220-18. DOI: http://dx.doi.org/10.1016/j.ecolmodel.2009.05.022

Ristić, Z. A., Marković, V., Dević, M. 2009: Development of hunting tourism in Vojvodina. Geographica Pannonica 13-3.

Stankowich, T. 2008: Ungulate flight responses to human disturbance. A review and meta-analysis. Conservation biology 141-9. DOI: http://dx.doi.org/10.1016/j.biocon.2008.06.026

Statistical Office of the Republic of Serbia, 2008: Opštine u brojakama. Belgrade.

Stedman, R., Diefenbach, D., Swope, C., Finely, J., Luloff, A., Zinn, H., Julian, H., Wang, G. 2004: Integrating wildlife and human-dimensions research methods to study hunters. Journal of wildlife management 762-4. DOI: https://doi.org/10.2193/0022-541X(2004)068[0762:IWAHRM]2.0.CO;2

Suchant, R., Baritz, R., Braunisch, V. 2003: Wildlife habitat analysis - a multidimensional habitat management model. Journal for nature conservation 10-4. DOI: http://dx.doi.org/10.1078/1617-1381-00026

Toïgo, C., Servanty, S., Gaillard, J-M., Brandt, S., Baubet, E. 2008: Disentangling natural from hunting mortality in an intensively hunted wild boar population. Journal of wildlife management $72-7$. DOI: http://dx.doi.org/10.2193/2007-378

Torres, R. T., Santosa, J., Linnell, J. D. C., Virgós, E., Fonseca, C. 2011: Factors affecting roe deer occurrence in a Mediterranean landscape, Northeastern Portugal. Mammalian biology 76-4. DOI: http://dx.doi.org/ 10.1016/j.mambio.2010.10.013

Virgós, E., Telléria, J. L. 1998: Roe deer habitat selection in Spain: constraints on the distribution of a species. Canadian journal of zoology 76-7. DOI: http://dx.doi.org/10.1139/z98-065

Vospernik, S., Reimoser, S. 2008: Modelling changes in roe deer habitat in response to forest management. Forest ecology and managemet 255, 3-4. DOI: http://dx.doi.org/10.1016/j.foreco.2007.09.036

Zakon o divljači i lovstvu. Službeni Glasnik Republike Srbije 18/10. Beograd. 